\title{
Transformacja i globalna ekspansja brazylijskiego przemysłu lotniczego na przełomie XX i XXI wieku na przykładzie koncernu EMBRAER
}

\section{WPROWADZENIE}

W 2009 roku mija 40 lat od utworzenia najważniejszego brazylijskiego przedsiębiorstwa lotniczego Embraer (Empresa Brasileira de Aeronautica). Początki rozwoju tej gałęzi przemysłu w Brazylii wiążą się z polityką industrializacji, prowadzoną przez kolejne rządy od lat 30. XX w. oraz aktywną rolą kierowniczych kręgów armii. Z militarnego punktu widzenia oraz pozycji Brazylii w Ameryce Południowej i południowej części Atlantyku posiadanie dobrze rozwiniętego lotnictwa było sprawą kluczową, aby odgrywać znaczącą rolę w geopolityce regionu. Z punktu widzenia cywilnych i gospodarczych potrzeb tego rozległego kraju, o słabo rozwiniętej sieci kolejowej i drogowej oraz trudnych warunkach do jej rozbudowy, rozwój transportu lotniczego był bardzo ważnym elementem integracji społecznej i gospodarczej. Biorąc pod uwagę powyższe uwarunkowania, rozwój krajowego przemysłu lotniczego stawał się koniecznością, której byli świadomi zarówno rządzący technokraci, jak i kręgi wojskowe. Mając na uwadze bezpieczeństwo narodowe, zdawano sobie sprawę, iż nie można polegać na importowanym sprzęcie lotniczym ani pozwolić, aby jego krajowa produkcja była kontrolowana przez obce firmy. Podjęto więc aktywne prace w celu opracowania własnych technologii i prototypów, które mogłyby wejść do seryjnej produkcji. Powstanie i rozwój przedsiębiorstwa Embraer jest przykładem udanej industrializacji sterowanej przez państwo, a także udanej prywatyzacji i restrukturyzacji w latach 90. XX w. Jak podkreślają badacze, Embraer jest jedynym brazylijskim przedsiębiorstwem przemysłu wysokich technologii, które odniosło globalny sukces i jedynym rodzimym eksporterem produktów hightech na rynki światowe (Cassiolato i in. 2003, Goldstein 2002, Mitcheli 2005).

Celem pracy jest prześledzenie historii rozwoju Embraera, ze szczególnym uwzględnieniem procesów restrukturyzacji i prywatyzacji w połowie lat 90 . XX w. umożliwiających odzyskanie pozycji na rynkach krajowych i międzynarodowych oraz globalną ekspansję tego koncernu. Badania oparto o dostępne pozycje literatury analizujące początkowy rozwój firmy, jej przekształcenia na przełomie XX i XXI w. oraz raporty i sprawozdania roczne publikowane przez koncern Embraer. 


\section{POCZĄTKI ROZWOJU PRZEMYSŁU LOTNICZEGO}

Pierwszy samolot w Brazylii zbudowano w 1910 r. W następnych latach brazylijski przemysł lotniczy opierał się głównie na produkcji małych samolotów montowanych na licencji firm pochodzących z Europy Zachodniej lub USA, takich jak: Focke-Wulf Flugzeugbau AG, Caudron, Fairchild (Mattos 2006, Frischtak 1992).

Początki brazylijskiego przemysłu lotniczego należy jednak wiązać z powstałym w styczniu 1941 r. Ministerstwem Lotnictwa. Odegrało ono decydującą rolę w finansowym i politycznym wspieraniu kształcenia przyszłych inżynierów lotnictwa oraz rozwijaniu badań nad konstrukcją i budową pierwszych rodzimych samolotów. W styczniu 1946 r. powołano Komisję ds. Organizacji Centrum Technologii Lotniczych (Comissão de Organização do Centro Técnico de Aeronáutica - COCTA), która po przeprowadzeniu studiów wybrała miasto São Jose dos Campos jako miejsce lokalizacji tworzonego Centrum Technologii Lotniczych (CTA - Centro Tecnologico Aerospacial). Formalnie zostało ono utworzone w 1953 r., a działalność rozpoczęło od stycznia 1954 r. (Matos 2006, Embraer timeline 2009). W 1947 r. uruchomiono studia z inżynierii lotnictwa przy Wojskowym Instytucie Inżynieryjnym w Rio de Janeiro, które następnie przeniesiono do powstałego w $1950 \mathrm{r}$. Instytutu Technologii Lotniczych (Instituto Tecnologico Aeronautica - ITA) w São Jose dos Campos. Inspiratorem powstania Instytutu i aktywnym jego twórcą w pierwszym okresie był pułkownik Casimiro Montenegro Filho, późniejszy marszałek lotnictwa. Wizytował on amerykańskie szkoły kształcące inżynierów lotnictwa, m.in. Massachusetts Institute of Technology (MIT) oraz Air Force Institute of Technology, i sprowadził do pracy pierwszych wykładowców, co umożliwiło otwarcie studiów. Pierwszym rektorem ITA został ściągnięty z MIT prof. Richard Herbert Smith. Zatrudniono także inżynierów niemieckich, z najbardziej znanym konstruktorem profesorem Heinrichem Focke. W początkowym okresie w skład Centrum Technologii Lotniczych (CTA) wchodziły dwie jednostki Instytutu Technologii Lotniczych (ITA) oraz Instytut Badań i Rozwoju (Instituto de Pesquisas e Desenvolvimento - IPD) (Matos 2006, Frischtak 1992, Embraer timeline 2009).

W 1954 r. powstało pierwsze prywatne przedsiębiorstwo lotnicze: Indústria Aeronáutica Neiva, początkowo z siedzibą w Rio de Janeiro, a od 1956 r. w Botucatu, gdzie rozpoczęto produkcję pierwszego małego samolotu Paulistinha. W latach 70. XX w. firma ta we współpracy z Embraerem produkowała małe samoloty pasażerskie na licencji amerykańskiej firmy Piper. W 1980 r. większościowy pakiet akcji przejął Embraer i przeniósł do zakładów Neivy w Botucatu całą produkcję małych samolotów z głównym modelem Ipanema oraz rozpoczą stopniową „naturalizacje”" montowanych na licencji Pipera małych awionetek, wykorzystując krajowe części i podzespoły (Embraer timeline 2009).

W 1965 r. minister lotnictwa generał Edwardo Gomes podpisał dokumenty rozpoczynające prace nad budową dwusilnikowego samolotu pasażerskiego Bandeirante, które miał prowadzić Instytut Badań i Rozwoju (IPD) przy współudziale francuskiego inżyniera Maxa Holste ${ }^{1}$. Pierwszy lot prototypu Bandeirante odbył się 22 października 1968 r. W następnym roku przeprowadzono dalsze próby i udoskonalenia prototypu, przygotowując go do seryjnej produkcji. W tym celu 19 sierpnia 1969 r. postanowiono utworzyć państwowe

${ }^{1}$ Po opracowaniu pierwszego prototypu Bandeirante Max Holste skłócony ze swoimi brazylijskimi współpracownikami i niedowierzający w ich możliwości seryjnej produkcji Bandeirante, opuścił zespół projektowy i przeniósł się do Urugwaju (Matos 2006, s. 24). 
przedsiębiorstwo Embraer - Empresa Brasileira de Aeronáutica S.A. Początkowe zatrudnienie nieznacznie przekraczało 500 pracowników. Robotnicy montażowi pochodzili głównie z zakładów przemysłu samochodowego rozwiniętego w Brazylii w drugiej połowie lat 50. XX w., natomiast trzon kadry kierowniczej, inżynierskiej i projektowej pochodził głównie z IPD (Cassiolato i in. 2003). Początkowo dysponowano jednym hangarem, w którym można było produkować 2 samoloty miesięcznie. W 1969 r. Ministerstwo Lotnictwa złożyło zamówienie na 80 samolotów Bandeirante, zapewniając tym samym ekonomiczny byt przedsiębiorstwa w początkowej fazie rozwoju. Embraer rozpoczął działalność 2 stycznia 1970 r., lokalizując się w sąsiedztwie Centrum Technologii Lotniczych (CTA) w São Jose dos Campos (Embraer timeline 2009).

\section{PIERWSZA FAZA ROZWOJU}

Na początku lat 70. poza wprowadzeniem do seryjnej produkcji modelu Bandeirante (EMB-110/111) Instytut Badań i Rozwoju (IPD) opracował także model małego samolotu Ipanema (EMB-200), służącego głównie do opryskiwania pól uprawnych. W 1971 r. jego seryjną produkcję przekazano do zakładów Embraera. Te dwa modele, których koszty opracowania i budowy prototypów pokryło państwo, finansujące działalność badawczo-rozwojową Instytutu Badań i Rozwoju (IPD), będącego częścią Centrum Technologii Lotniczych (CTA), stanowiły podstawową ofertę powstającego Embraera. Ich wprowadzenie do produkcji nie wiązało się z długotrwałym i kosztownym dla firmy procesem badań, przygotowania i testowania prototypów, co obniżyło koszty funkcjonowania przedsiębiorstwa w początkowym okresie. Ponadto wraz z przekazaniem tych modeli do produkcji Embraer przejął sporą część inżynierów pracujących w IPD przy konstrukcji tych modeli, tworząc tym samym wewnętrzny departament badań i rozwoju (Cassiolato i in. 2003, Frischtak 1992).

Drugim sposobem na stosunkowo tanie i szybkie pozyskanie nowych modeli do produkcji było podpisywanie umów licencyjnych z zagranicznymi firmami lotniczymi. Pierwszą taką umowę podpisano w 1971 r. z włoską firmą Aermacchi na produkcję na licencji samolotu wojskowego Xavante (EMB-326GB). W 1974 r. weszło w życie porozumienie $\mathrm{z}$ amerykańską firmą Piper Aircraft Company na produkcję licencyjną kilku modeli małych samolotów cywilnych: Navajo (EMB-820), Sêneca (EMB-810), sześcioosobowe Sertanejo (EMB-721) i Minuano (EMB-720). Natomiast w zakładach podległych Embraerowi Indústria Aeronáutica Neiva zaczęto produkcję czteroosobowych modeli Carioca (EMB710), Corisco (EMB-711) i Tupi (EMB-712). W 1980 r. Brazylijskie Siły Lotnicze (FAB) zgłosiły zapotrzebowanie na nowy model bombowca szturmowego, do którego produkcji Embraer stworzył spółkę joint venture z włoskimi firmami Aeritalia - współcześnie Alenia (46\% udziałów) oraz Aermacchi (24\% udziałów). Miała ona opracować i wdrożyć do produkcji model samolotu oznaczony symbolem AMX. Pierwszy lot prototypu AMX odbył się w 1985 r., a pierwsze samoloty dotarły do Brazylijskich Sił Lotniczych w 1989 r. Ostatnim dużym przedsięwzięciem o charakterze joint venture był projekt 12-X podpisany z argentyńską FAMA (Fabrica Militar de Aviones) na fali politycznej współpracy w ramach tworzonego MERCOSUR. Celem projektu było opracowanie modelu zastępującego wysłużonego Bandeirante, jednakże okazał się on największą porażką finansową Embraera i przyczynił się, 
w opinii niektórych autorów, do kryzysu finansowego firmy na początku lat 90. (Cassiolato i in. 2003, Frischtak 1992).

Embraer nie był jednakże tylko biernym odbiorcą licencji od firm z państw wysokorozwiniętych. Już w połowie lat 70. rozpoczął własne prace badawczo-rozwojowe i zaczął wprowadzać nowe modele samolotów. Pierwszym z nich był wyprodukowany w 1976 r. turbośmigłowy samolot dla biznesu Xingu (EMB-121). W 1978 r. Brazylijskie Siły Lotnicze podpisały z Embraerem kontrakt na zaprojektowanie i budowę turbośmigłowego samolotu szkoleniowego dla wojska, co doprowadziło do powstania modelu Tucano (EMB-312). Wszedł on do seryjnej produkcji w 1980 r. i poza zamówieniami dla brazylijskiej armii stał się jednym z hitów eksportowych Embraera² .

$\mathrm{Na}$ początku lat 80 . XX w. firma zaczęła również prace nad turbośmigłowym samolotem pasażerskim obsługującym połączenia regionalne średniego zasięgu i mogącym przewozić do 30 osób - model Brasilia (EMB-120), który pierwszy lot odbył w 1983 r., a do służby wszedł w 1985 r. Następnym modelem przeznaczonym na cywilny rynek był Vector (CBA123), turbośmigłowy samolot z 19 miejscami, przeznaczony do przewożenia biznesmenów, wojskowych i kadry kierowniczej. Prace nad nim rozpoczęto w 1988 r., pierwszy lot odbył się w 1990 r., jednakże ze względu na wysoką cenę nie cieszył się on zainteresowaniem odbiorców. Ostatnim projektem, nad którym prace rozpoczęto przed kryzysem (w 1989 r.), był model EMB 145 - pierwszy pasażerski odrzutowiec średniego zasięgu w historii Embraera. Pogorszenie sytuacji finansowej firmy na początku lat 90. XX w. zatrzymało jednak prace nad tym modelem aż do 1994 r., kiedy to wraz z prywatyzacją firmy powrócono do tego projektu (Frischtak 1992, Embraer timeline 2009)

Wprowadzone do produkcji w latach 80 . modele samolotów okazały się niezbyt konkurencyjne cenowo na światowych rynkach. Dodatkowo recesja na rynku lotniczym na początku lat 90. XX w. sprawiła, że firma wpadła w kłopoty finansowe, które doprowadziły ją do krawędzi bankructwa. Kredyty zaciągnięte na zaprojektowanie i wdrożenie do produkcji nowych modeli stały się, ze względu na spadającą wielkość sprzedaży coraz trudniejsze do obsługi. Model Brasilia (EMB 120), który miał być głównym źródłem dochodów firmy na rynkach międzynarodowych, okazał się mało konkurencyjny cenowo i relatywnie drogi w eksploatacji, dlatego też w latach 1985-2001 sprzedano zaledwie 356 sztuk tego samolotu do 14 państw, przy czym największym odbiorcą były Stany Zjednoczone. Jeszcze bardziej nietrafiony okazał się model Vector (CBA 123), który nie wszedł do produkcji seryjnej (Frischtak 1992, Cassiolato i in. 2003).

\section{KRYZYS I PRYWATYZACJA}

Wspomniany powyżej kryzys na rynku lotniczym, powodujący spadek zamówień na samoloty pasażerskie, pokrył się z podobną sytuacją w sektorze zbrojeniowym i związane z tym ograniczenia zakupu samolotów wojskowych. Dodatkowym czynnikiem osłabiającym pozycję firmy było ogólne załamanie gospodarki brazylijskiej na początku lat 90 . XX w., związane z transformacją gospodarczą, liberalizacją polityki handlowej oraz zniesieniem

${ }^{2}$ W latach 1980-1991 sprzedano ponad 600 tych samolotów dla sił powietrznych 12 krajów, m.in. 131 samolotów dla brytyjskich Royal Air Force, 80 dla francuskich sił powietrznych oraz 120 dla egipskich sił powietrznych (Frischtak 1992, s. 10-11). 
wsparcia finansowego dla firm eksportowych. Wraz z demokratyzacją i odsunięciem od władzy wojskowych, Embraer stracił wsparcie związanych z nim wpływowych grup nacisku. Ograniczenie wydatków rządowych wpłynęło na zmniejszenie zamówień na samoloty wojskowe, a także na B\&R. Wstrzymanie przez rząd finansowego wsparcia dla Embraera oraz liberalizacja wymiany handlowej w tak radykalny sposób, że w efekcie faworyzowany był import, wpłynęły na gwałtowny spadek konkurencyjności firmy na rynku krajowym i międzynarodowym. Kryzys, który dotknął Embraera, był także częściowo wynikiem nieodpowiedniej polityki rozwojowej firmy, która objawiała się:

- brakiem dokładnych badań marketingowych określających potencjalne zapotrzebowanie rynku,

- nadmiernym skupieniem się managerów Embraera na technologicznych możliwościach i nowoczesności produktów, a nie sprawach finansowych,

- zlekceważeniem względów kosztowych, w wyniku czego wprowadzane na rynek modele były bardziej technologicznie zaawansowane niż konkurentów, jednakże znacznie droższe, zarówno w momencie zakupu, jak i w eksploatacji (Cassiolato i in. 2003 s. 41; Frischtak 1992 s. $35-45)$.

Coraz trudniejsza sytuacja finansowa firmy wymusiła gwałtowne redukcje zatrudnienia. W 1990 r. łączna strata przedsiębiorstwa wyniosła 265 mln USD, a zatrudnienie zmniejszono o 3994 pracowników, czyli o ok. 32\% w porównaniu z wcześniejszym rokiem (ryc. 1 i 2). W kolejnych latach sytuacja ulegała dalszemu pogorszeniu, szczególnie w przypadku zatrudnienia, które systematycznie redukowano aż do poziomu ok. 3,8 tys. osób w 1996 r. (ryc. 1). Wynikało to nie tylko z sytuacji finansowej firmy, ale także podjętej akcji restrukturyzacyjnej ograniczającej nadmierne zatrudnienie.

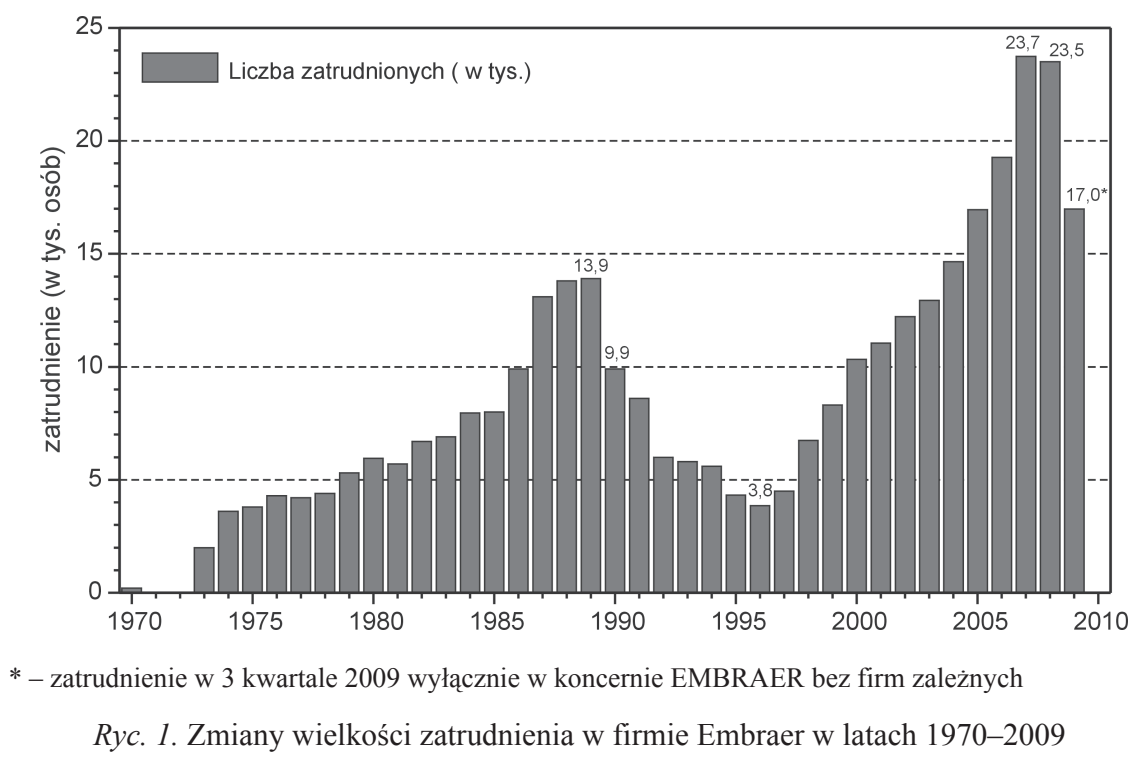

Źródło: opracowanie własne na podstawie: Cassiolato i in. 2003, s. 63, Embraer Annual Report (lata 1999-2008) oraz Embraer in Numbers, 2009 
W 1992 r. Embraer został włączony do narodowego planu prywatyzacji i pod dokonaniu najboleśniejszych - z punktu widzenia społecznego - redukcji kadrowych i restrukturyzacji, które wziął na siebie rząd, został przeznaczony na sprzedaży. Firmę sprzedano 7 grudnia 1994 r. za 265 mln USD konsorcjum składającemu się z brazylijskich firm i funduszy emerytalnych, którym przewodził Bozano Simonsen Group, będący jednym z największych brazylijskich konglomeratów finansowych, działający w sektorach finansów i nieruchomości, górniczym, rolniczym i przemysłowym.

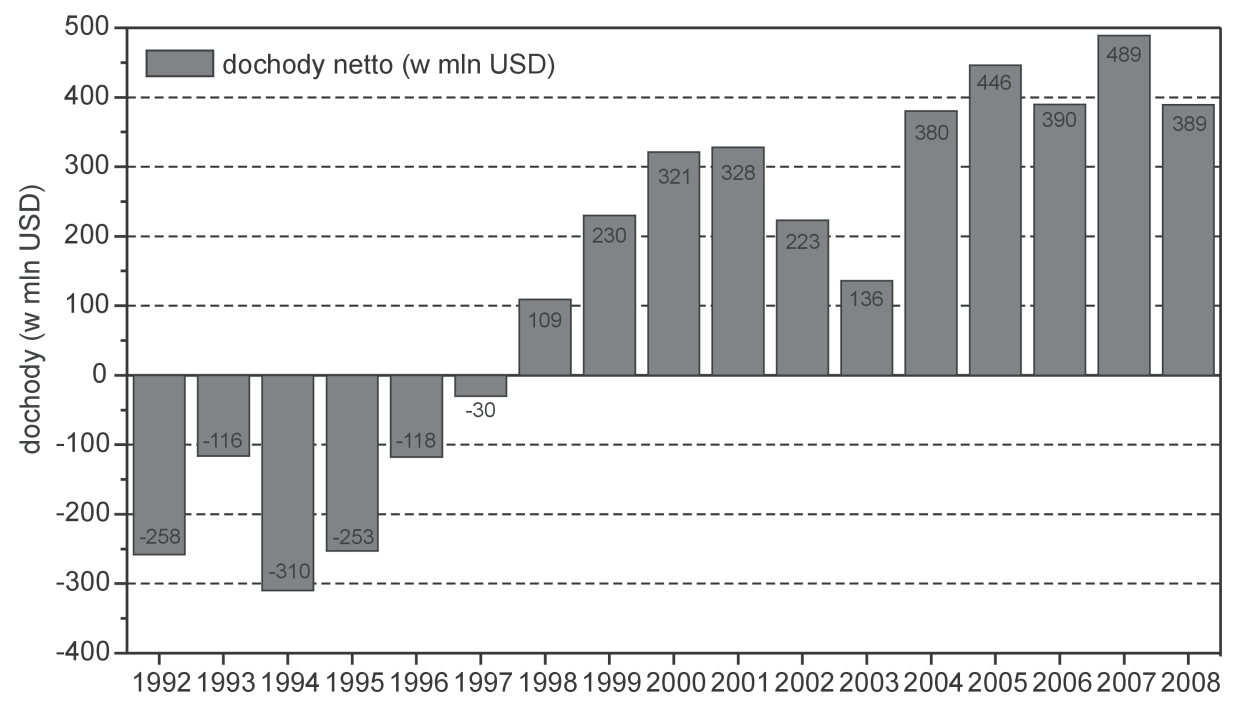

Ryc. 2. Zmiany wielkości dochodów netto firmy Embraer w latach 1992-2008

Źródło: opracowanie własne na podstawie: Goldstein 2002, s. 103, Embraer Annual Report (lata 1999-2008) oraz Embraer in Numbers, 2009

Konsorcjum nabyło 40\% akcji Embraera, a jego głównymi udziałowcami były: Bozano Simonsen Ltd. (13,65\%), Bozano Leasing (3,63\%), fundusze emerytalne: Sistel $(10,42 \%)$ i Previ (10,40\%) oraz Fundacja Cesp (1,9\%). Dla pracowników zarezerwowano 10\% akcji, natomiast rządowi pozostało $6,8 \%$ akcji, w tym tzw. złota akcja z prawem veta w najważniejszych sprawach związanych z rozwojem firmy. W umowie prywatyzacyjnej wpisano również klauzulę ograniczającą udział zagranicznych właścicieli do $40 \%$ akcji (Cassiolato i in. 2003, s. 42, Goldstein 2002, s. 102-103).

Prywatyzacja firmy nie zakończyła procesu restrukturyzacji i przekształceń zmierzających do obniżenia kosztów i skrócenia czasu produkcji. W maju 1996 r., kiedy zatrudnienie w Embraerze spadło do 3849 osób, robotnicy zgodzili się na obniżki płac oraz skrócenie i uelastycznienie czasu pracy, co znacznie zmniejszyło wielkość strat w porównaniu z poprzednimi latami (ryc. 2). Przeprowadzone zmiany znacząco zwiększyły produktywność i przyspieszyły proces produkcyjny. W latach 1990-1996 czas produkcji samolotu Brasilia zmniejszył się z 16 do 9 miesięcy (Goldstein 2002, s. 104).

Wraz z prywatyzacją ponownie wrócono do projektu budowy regionalnego odrzutowca pasażerskiego o pojemności do 50 miejsc - projekt EMB-145. Do projektu włączyło się 4 partnerów dzielących ryzyko (risk-sharing partners): (Gamesa (Hiszpania), C\&D (USA), ENAER (Chile) i Sonaca (Belgia), a współudział zgłosiło 350 poddostawców i partnerów 
(m.in. Rolls Royce, Honeywell, TRW Lucas, Goodrich, Liebherr, Hamilton Sundstrand, Parker Aerospace, Thales i EATON. Ponowne prace nad tym modelem postępowały bardzo sprawnie i już 11 sierpnia 1995 r. odbył się pierwszy lot EMB-145. W następnym roku samolot uzyskał wymagane certyfikaty, co umożliwiło skierowanie go do sprzedaży. Pierwsza prezentacja dla komercyjnych odbiorców w podczas targów lotniczych w Farnborough w Wielkiej Brytanii w 1996 r. zakończyła się dużym sukcesem, gdyż 200 sztuk nowych EMB-145 zostało sprzedanych północnoamerykańskim liniom Continental Express, przy czym pierwszą z zamówionych maszyn dostarczono już 27 grudnia tego samego roku (Cassiolato i in. 2003, Embraer timeline 2009).

\section{WYJŚCIE Z KRYZYSU}

Wprowadzony do produkcji w 1996 r. model ERJ-145³ okazał się wielkim sukcesem komercyjnym Embraera, umożliwiającym unikniecie bankructwa i uzdrowienie sytuacji finansowej firmy. Zapoczątkował on także rodzinę samolotów powstałych na jego bazie. W 1997 r. rozpoczęto prace nad modelami ERJ-135 (37-miejscowy) oraz ERJ-140 (40-miejscowy) powstałymi na bazie ERJ-145 i wykorzystującymi większość części i podzespołów z tego modelu (Cassiolato i in. 2003; Embraer timeline 2009).

W kolejnych latach gwałtownie rosła wielkość sprzedaży firmy. W 1997 r. na targach lotniczych w Le Bourget pod Paryżem Embraer podpisał kontrakt na dostawę 67 ERJ-145 dla American Eagle wart blisko 1 mld USD. W 1998 r. na tych samych targach Embraer zdobył kontrakty warte łącznie 6,6 mld USD, co było wówczas rekordową wartością w światowym przemyśle lotniczym (Cassiolato i in. 2003, s. 42-43). Pozwoliło to firmie osiagnąć na koniec tego roku dochód w wysokości 109 mln USD i zwiększyć zatrudnienie do ponad 6,7 tys. osób (ryc. 1 i 2).

Poprawa sytuacji firmy i gwałtowny wzrost jej znaczenia na światowym rynku regionalnych odrzutowców, wzmógł rywalizację z jej największymi konkurentami, a w szczególności z kanadyjskim Bombardierem, będącym do tej pory niezagrożonym liderem w tym segmencie rynku lotniczego. Spory między tymi dwiema firmami, a w późniejszym okresie także rządami Kanady i Brazylii oraz pod jurysdykcją WTO toczyły się w latach 1996-2002. Dwustronne negocjacje między krajami zakończyły się w maju 2003 r. bez żadnych formalnych porozumień (szerzej patrz Goldstein, McGuire 2004).

Po sukcesie sprzedażowym rodziny odrzutowców ERJ-145 w 1999 r. Embraer rozpoczął nowy program budowy większych odrzutowców pasażerskich z rodziny Embraer 170/190 o pojemności od 70 do 118 miejsc. Budżet programu wynosił $850 \mathrm{mln}$ USD, a włączyło się do niego 16 partnerów dzielących ryzyko i 22 głównych dostawców. Znaczenie tego programu było bardzo duże, gdyż Embraer wchodził na nowy rynek większych odrzutowców, który do tej pory był zdominowany przez Boeinga, McDonnell Douglasa i Airbusa. W tym samym roku Embraer sprzedał 20\% swoich akcji konsorcjum francuskich firm lotniczych, w skład którego wchodziły: Aerospatiale Matra (5,67\%), Dassault Aviation (5,67\%), Thomson-CSF $(5,67 \%)$ i Snecma $(2,99 \%)$. Działania te wiązały się z nową strategią firmy zmierzająca do pozyskania nowych technologii, produktów i rynków, nie zmieniały one jednak ogólnej

3 W 1998 r. Embraer zmienił akronimy oznaczeń samolotów z rodziny EMB-145 na ERJ-145 (Embraer Regional Jet). 
kontroli nad firmą, która pozostawała w rękach brazylijskich firm Bozano Simonsen Group (20\%), funduszy emerytalnych Previ (20\%) i Sistel (20\%) oraz rządu (3,2\%) i innych firm $(16,7 \%)$. Z tą strategią wiąże się także wejście firmy na giełdę w São Paulo oraz Nowym Jorku w 2000 r. (Cassiolato i in. 2003, s. 43, Embraer timeline 2009).

Poza pracami nad nową rodziną odrzutowców pasażerskich, Embraer postanowił w 2000 r. ponownie wejść także na rynek luksusowych samolotów dla biznesu (corporate aviation), rozpoczynając program budowy odrzutowców Legacy na bazie wcześniejszego modelu ERJ-135. Prace nad nim zakończyły się w 2001 r., kiedy odbył się pierwszy lot tego samolotu, a do końca roku uzyskano potrzebne do użytkowania certyfikaty. W tym samym roku wyprodukowano także pierwszy model Embraera 170, należącego do nowej rodziny Embraer 170/190. Odbył on swój pierwszy lot już w lutym 2002 r., natomiast pierwsze dostawy do odbiorców dotarły dwa lata później. Do stycznia 2005 r. wszystkie cztery modele z tej rodziny weszły do seryjnej produkcji (Embraer timeline 2009).

Dzięki udanemu wprowadzeniu do sprzedaży nowych modeli, cieszących się dużą popularnością na rynkach światowych, sytuacja ekonomiczna firmy uległa zdecydowanej poprawie. Gwałtownie wzrosła wielkość sprzedaży, osiagając w 2008 r. poziom ponad 6,3 mld USD, a dochody netto sięgnęły blisko 390 mln USD. Większość produkcji (96\%) kierowano zagranicę, co stawiało firmę w gronie największych brazylijskich eksporterów (ryc. 2 i 3 ) (Mitchell 2005). Wraz z rozwojem koncernu i wzrostem produkcji zwiększyło się także zatrudnienie. Już w 2004 r. przekroczyło 14,6 tys. osób, czyli najwyższy poziom z okresu przed prywatyzacją (w 1989 r. wynosiło ono 13,9 tys. osób). W ostatnich latach zatrudnienie dalej wykazywało silną tendencję wzrostową, a w 2008 r. wynosiło aż 23,5 tys. osób (ryc. 1).

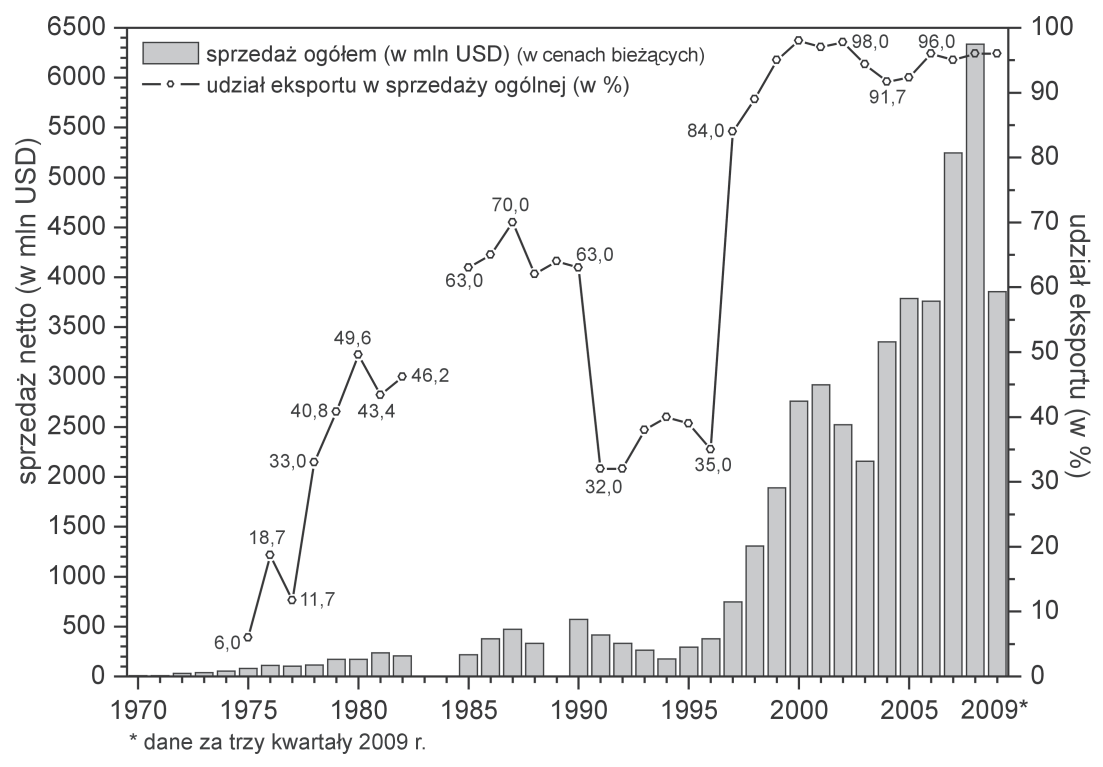

Ryc. 3. Zmiany udziału eksportu w sprzedaży oraz wielkości sprzedaży ogółem firmy Embraer w latach 1970-2009

Źródło: opracowanie własne na podstawie: Ramamurti 1985, s. 259 i 268, Goldstein 2002, s. 103, Embraer Annual Report (lata 1999-2008) oraz Embraer in Numbers, 2009 
Również wielkość produkcji samolotów wykazuje znaczy wzrost w porównaniu z pierwszą połową lat 90 . XX w. (ryc. 4). W strukturze sprzedaży dominują samoloty pasażerskie, głównie przeznaczone do obsługi regionalnych połączeń lotniczych z rodziny ERJ-145 i Embraer 170/190. Ich udział we wpływach firmy dochodził w latach 1999-2001 do 85-89\%, natomiast obecnie kształtuje się w okolicy 2/3 ogólnej wielkości wpływów. Od 2000 r. coraz większe znaczenie w sprzedaży firmy odgrywa także segment samolotów biznesowych (corporate aviation), który stał się drugim pod względem znaczenia segmentem sprzedaży Embraera i stanowi obecnie ok. 14-16\% ogólnej wielkości przychodów (ryc. 5).

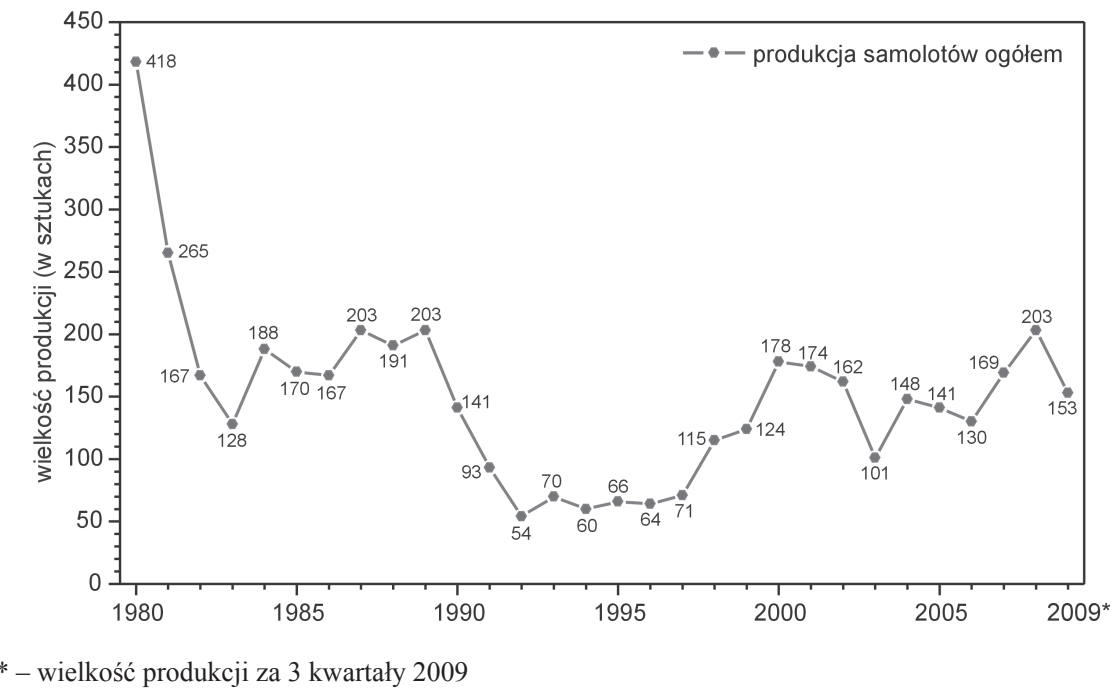

Ryc. 4. Zmiany ogólnej wielkości produkcji samolotów firmy Embraer w latach 1980-2009

Źródło: opracowanie własne na podstawie: Cassiolato i in. 2003, s. 49, Embraer Annual Report (lata 1999-2008) oraz Embraer in Numbers, 2009

Trzecim segmentem w ofercie firmy są samoloty wojskowe, które dostarczają w ostatnich kilku latach od 6 do 11\% ogólnej wielkości wpływów. Wraz ze wzrostem liczby samolotów Embraera będących w użytkowaniu, coraz większe znaczenie w przychodach firmy odgrywają także usługi serwisowe i sprzedaż części zamiennych. W ostatnich latach wielkość wpływów z tego tytułu przekraczała 10\% ogólnej wielkości sprzedaży (ryc. 5).

Wraz ze wzrostem popularności samolotów Embraera i wysokim udziale eksportu w ogólnej sprzedaży, znacznie poszerzyły sie także zagraniczne rynki firmy. W początkowym okresie głównym zagranicznym odbiorcą brazylijskich samolotów były towarzystwa lotnicze ze Stanów Zjednoczonych i Kanady, a w mniejszym stopniu także z Europy Zachodniej. W ostatnich latach wraz z ekspansją globalną koncernu coraz większą rolę odgrywają także nowe rynki zbytu w Azji, Ameryce Łacińskiej i na Bliskim Wschodzie. Nadal dominującą rolę odgrywa rynek Ameryki Pn., z którego pochodziło 43\% wpływów w 2008 r. Na kolejnych pozycjach znalazły się: Europa oraz region Azji i Pacyfiku, na które przypadało po 18\% wielkości wpływów w tym roku (ryc. 6). 


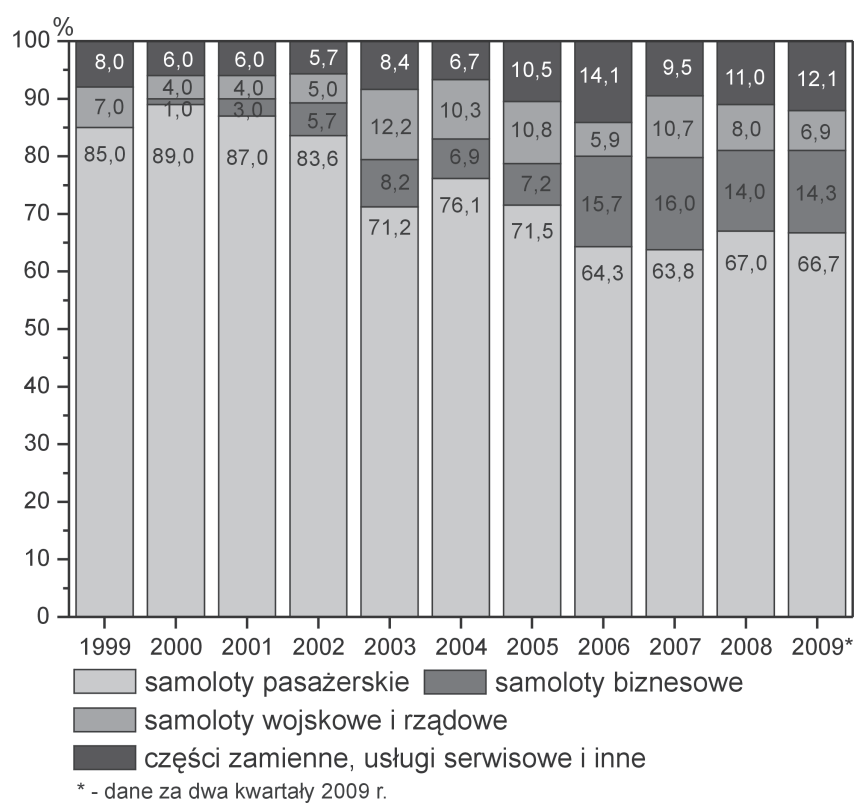

Ryc. 5. Zmiany struktury wpływów firmy Embraer wg głównych segmentów rynku lotniczego w latach 1999-2009

Źródło: opracowanie własne na podstawie: Embraer Annual Report (lata 1999-2008) oraz Embraer in Numbers, 2009

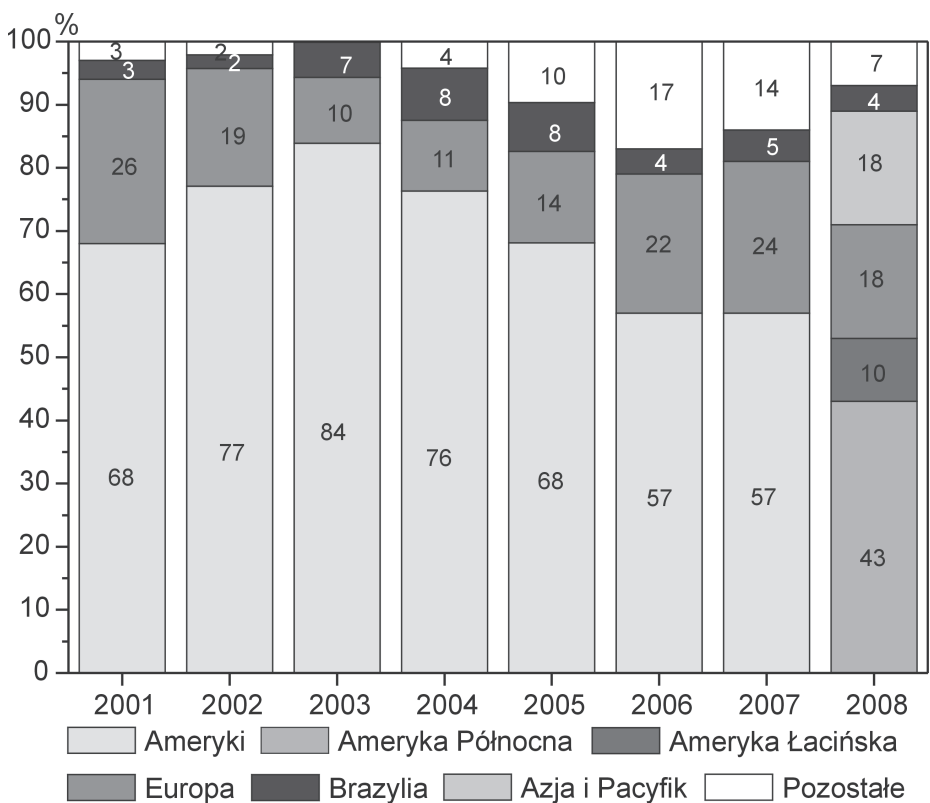

Ryc. 6. Zmiany geograficznej struktury wpływów firmy Embraer w latach 2001-2008 Źródło: opracowanie własne na podstawie: Embraer Annual Report (lata 1999-2008). 
Samoloty z rodziny ERJ-145 zostały zakupione przez 30 linii lotniczych z 23 państw, natomiast maszyny z rodziny Embraer 170/190 kupiło 55 linii lotniczych z 35 państw. Wśród odbiorców brazylijskich samolotów są także polskie linie LOT, które do końca 2009 r. zakupiły po 6 maszyn ERJ-145 i Embraer 175 oraz 10 samolotów Embraer 170, co daje im pierwsze miejsce w Europie pod względem liczby maszyn brazylijskiej firmy w eksploatacji (Embraer Annual Report 2008, 2009).

Największe znaczenie dla sytuacji finansowej firmy ma jednak sprzedaż samolotów pasażerskich o średniej pojemności i zasięgu. W tym segmencie Embraer i rywalizujący z nim kanadyjski Bombardier opanowały i podzieliły między siebie światowy rynek (Mitchell 2005). O sukcesie Embraera na tym polu zadecydowało wprowadzenie do sprzedaży od $1996 \mathrm{r}$. odrzutowców z rodziny ERJ-145, które od 2004 r. uzupełniły większe samoloty z rodziny Embraer 170/190. Te dwie rodziny samolotów stanowią obecnie główną ofertę handlową firmy i dostarczają największych przychodów (ryc. 7).

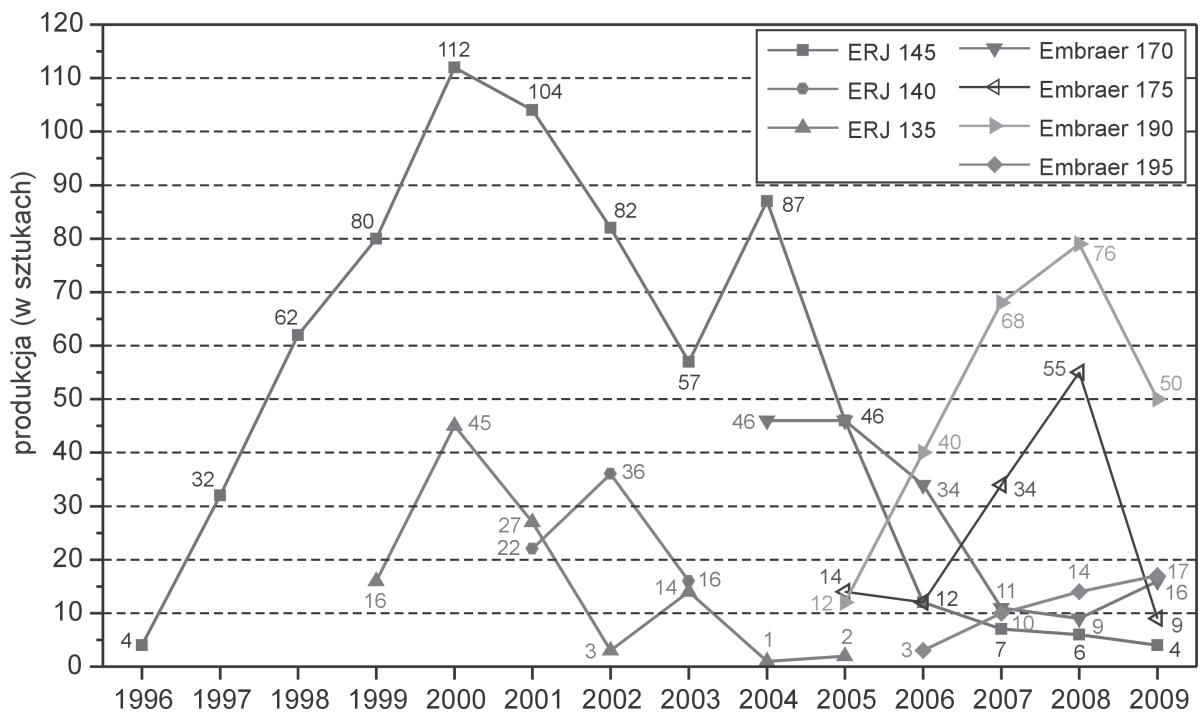

*dane za 2009 dotyczą tylko 3 kwartałów

Ryc. 7. Zmiany wielkości produkcji odrzutowców pasażerskich Embraera w latach 1996-2009*

Źródło: opracowanie własne na podstawie: Embraer Annual Report (lata 1999-2008) oraz Embraer in Numbers, 2009

W latach 1996-2009 Embraer wyprodukował 1461 samolotów pasażerskich z rodzin ERJ-145 i Embraer 170/190. Największą popularnością cieszy się model ERJ-145, którego produkcja w latach 1996-2009 w Brazylii osiągnęła poziom 697 sztuk, natomiast łącznie z produkcją w zakładach Harbin Embraer Aircraft Industry (HEAI), których brazylijski koncern jest współwłaścicielem, z końcem 2007 r. przekroczyła 1000 sztuk (tab. 1 oraz Embraer timeline 2009). 
W przypadku samolotów z rodziny Embraer 170/190 łączna produkcja osiagnęła poziom 582 sztuk, natomiast blisko 300 sztuk jest jeszcze na liście zamówień. Najpopularniejszym modelem z tej rodziny jest Embraer 190, którego produkcja przekroczyła 250 sztuk, a firma ma jeszcze zamówienia na 185 sztuk i opcje zakupu na dalsze 447 sztuk tego samolotu (tab. 1).

Tab. 1. Wielkość zamówień i produkcji odrzutowców pasażerskich Embraera w latach 1996-2009* (w sztukach)

\begin{tabular}{|c|c|c|c|c|c|c|}
\hline Typ samolotu & Pojemność & $\begin{array}{l}\text { Zasięg } \\
(\mathrm{w} \mathrm{km})\end{array}$ & Zamówienia & $\begin{array}{c}\text { Opcje } \\
\text { zakupu }\end{array}$ & Produkcja & $\begin{array}{c}\text { Zaległe } \\
\text { zamówienia }\end{array}$ \\
\hline \multicolumn{7}{|c|}{ Rodzina ERJ-145 } \\
\hline ERJ-135 & 37 & 3250 & 108 & - & 108 & \\
\hline ERJ-140 & 44 & 3050 & 74 & - & 74 & \\
\hline ERJ-145 & 50 & 2900 & 708 & 25 & 697 & 11 \\
\hline Ogółem & - & - & 890 & 25 & 879 & 11 \\
\hline \multicolumn{7}{|c|}{ Rodzina Embraer 170/190 } \\
\hline Embraer 170 & $70-80$ & 3900 & 194 & 96 & 164 & 30 \\
\hline Embraer 175 & $78-88$ & 3700 & 135 & 173 & 123 & 12 \\
\hline Embraer 190 & $98-114$ & 4500 & 436 & 447 & 251 & 185 \\
\hline Embraer 195 & $108-122$ & 4100 & 112 & 76 & 44 & 68 \\
\hline Ogółem & & & 877 & 792 & 582 & 295 \\
\hline LĄCZNIE & & & 1767 & 817 & 1461 & 306 \\
\hline
\end{tabular}

* dane za 2009 dotyczą tylko 3 kwartałów

Źródło: opracowanie własne na podstawie: Embraer in Numbers, 2009 oraz Embraer Annual Report 2008, 2009

\section{GLOBALNA EKSPANSJA}

W kilka lat po powstaniu Embraera jego kierownictwo zdało sobie sprawę z konieczności szukania zagranicznych odbiorców na swoje produkty, gdyż krajowy rynek nie gwarantował wystarczającej chłonności. Z końcem lat 70. XX w. podjęto intensywne działania w celu zwiększenia sprzedaży na rynku Stanów Zjednoczonych, który wykazywał duże zapotrzebowanie na oferowane przez Embraera samoloty. W 1979 r. otwarto pierwsze biuro sprzedaży i centrum obsługi technicznej Embraera w USA w mieście Dania na Florydzie, które w 1981 r. przeniesiono do Fort Lauderdale na Florydzie. Drugim ważnym rynkiem zbytu była Europa Zachodnia, w której pierwsze pierwsze biuro sprzedaży i centrum obsługi technicznej powstało w 1983 r. w Le Bourge pod Paryżem. Przez długi czas były to jedyne zagraniczne przedstawicielstwa firmy, świadczące usługi na dwóch głównych rynkach zbytu (Embraer timeline 2009).

Dalsza ekspansja zagraniczna firmy była możliwa dopiero po sukcesie samolotów z rodziny ERJ-145, które zyskały dużą popularność na rynkach światowych. Skłoniło to firmę do ekspansji na nowe rynki zbytu, co wiązało się z otwarciem w maju 2000 r. biura 
sprzedaży oraz centrum dystrybucyjno-serwisowego w Pekinie, a w grudniu tego roku centrum sprzedaży w Singapurze (Embraer timeline 2009).

Kolejnym wielkim krokiem w kierunku globalnej ekspansji firmy było zawarcie 2 grudnia 2002 r. spółki joint venture z AVIC II z Chin, w celu budowy fabryki produkującej regionalne odrzutowce z rodziny ERJ-145 w Harbinie. Wynikało to $\mathrm{z}$ faktu, iż rynek regionalnych przewozów lotniczych w Chinach wykazywał najwyższą na świecie dynamikę wzrostu, zaś perspektywa Igrzysk Olimpijskich w 2008 r. w Pekinie pozwalała przypuszczać, że tendencja ta zostanie utrzymana, a nawet wzmocniona. Budowa fabryki w Harbinie w kooperacji z chińskim partnerem była też częściowo wymuszona naciskami władz chińskich, które uzależniały dalsze zamówienia od lokalizacji cześsi produkcji w Chinach. Te dwa czynniki ostatecznie przekonały władze Embraera do powołania spółki Harbin Embraer Aircraft Industry (HEAI), która miała zająć się montażem i produkcją regionalnych odrzutowców z wprowadzonej wcześniej rodziny ERJ-145. Embraer zagwarantował sobie większościowy udział 51\% akcji firmy oraz 4 z 7 członków rady nadzorczej. Budowa zakładu przebiegała bardzo szybko, już w rok od powstania spółki - 16 grudnia 2003 r. zaprezentowano pierwszy samolotu ERJ 145 z fabryki w Harbinie i zarazem pierwszy wyprodukowany poza Brazylią (Embraer timeline 2009, Goldstein 2006).

Koncern rozwijał także swoją działalność na wcześniej opanowanych rynkach. W 2002 r. otwarto centrum serwisowo-remontowe w Nashville w stanie Tennessee w USA. W 2004 r. powołane przez Embraera i EADS (European Aeronautic Defense and Space Company) konsorcjum wygrało przetargu na zakup większościowych udziałów portugalskiego przedsiębiorstwa lotniczego OGMA (Industria de Aeronautica de Portugal S.A.). W następnych latach Embraer rozwinął sieć sprzedaży i centrów serwisowych, uruchamiając w $2006 \mathrm{r}$. centrum tego typu w Villepinte, w sąsiedztwie lotniska Charlesa de Gaulle'a pod Paryżem. Rozbudował także sieć centrów obsługi odrzutowców biznesowych, które powstały w 2006 r. w Alverca w Portugalii w przejętych zakładach OGMA oraz w 2008 r. w Mesa w Arizonie, Windsor Locks w Connecticut, Fort Lauderdale na Florydzie (Embraer timeline 2009).

Najnowszą zagraniczną inwestycją Embraera było rozpoczęcie 4 grudnia 2008 r. budowy montowni odrzutowców biznesowych Embraer oraz centrum serwisowego w Melbourne City na Florydzie, której uruchomienie jest planowane w 2010 r. (Embraer timeline 2009).

Rozwój produkcji i globalnej ekspansji firmy nie byłby możliwy bez rozbudowy jej potencjału produkcyjnego w Brazylii. Centrum produkcyjne i główna siedziba Embraera zlokalizowane jest w mieście São Jose dos Campos w stanie São Paulo. Drugim ośrodkiem produkcji jest miasto Botucatu, w którym znajduje się siedziba przejętej w 1980 r. firmy Indústria Aeronáutica Neiva, specjalizującej się w produkcji małych samolotów rolniczych (Ipanema) oraz awionetek pasażerskich. W 1999 r. Embraer powołał do spółki ze szwajcarską firmą Liebherr Group spółkę joint venture Embraer Liebherr Equipamentos do Brasil S.A. (ELEB) z siedzibą w São Jose dos Campos. W celu zwiększenia mocy produkcyjnych w 2001 r. oddano do użytku nowy kompleks produkcyjny Eugênio de Melo w São Jose dos Campos oraz podpisano porozumienie o budowie nowego kompleksu w mieście Gavião Peixoto na pn. zach. od São Paulo, gdzie już jesienią tego samego roku oddano do użytku prawie pięciokilometrowy pas startowy (jeden z najdłuższych na świecie) oraz pierwsze hangary produkcyjne. Inauguracja kompleksu odbyła się w połowie 2002 r., a w późniejszym okresie przeniesiono do niego produkcję samolotów wojskowych oraz biznesowych. Najnowszą inwestycją firmy było rozpoczęcie w 2008 r. budowy kompleksu przemysłowego w mieście Taubate, w którym uruchomiono centrum dystrybucji materiałów i części (Embraer timeline 2009). 


\section{PodsumowANIE}

Historię rozwoju i przemian Embraera można podzielić na trzy główne fazy. Pierwsza z nich, obejmująca okres od 1969 r. do drugiej połowy lat 80. XX w., cechowała się dynamicznym rozwojem $\mathrm{w}$ oparciu głównie o samoloty opracowane w ramach finansowanych przez państwo projektów lub zakup licencji od firm amerykańskich, europejskich. Tak prowadzona współpraca pozwoliła na podniesienie kwalifikacji pracowników i zdobycie doświadczenia potrzebnego do rozwoju samodzielnej produkcji. W tym okresie rozwój przemysłu lotniczego nawiązywał do realizowanej ogólnej strategii industrializacji poprzez substytucję importu, która cechowała się dążeniem do możliwie najbardziej samodzielnej produkcji jak najszerszej gamy sprzętu lotniczego.

Druga faza, trwająca od końca lat 80 . do połowy lat $90 \mathrm{XX}$ w., to okres kryzysu brazylijskiego przemysłu lotniczego, objawiającego się gwałtownym spadkiem produkcji i redukcją zatrudnienia. Wynikało to $z$ jednej strony ze zmiany polityki wspierania tej gałęzi przemysłu przez władze centralne, a $z$ drugiej strony $z$ liberalizacji wymiany handlowej i zniesienia programów wspierających eksport brazylijskich towarów. Na trudną sytuację Embraera w tej fazie złożyła się także rosnąca konkurencja na rynkach światowych, która nasiliła się wraz z kryzysem w lotnictwie pasażerskim oraz spadkiem wydatków na sprzęt wojskowy na początku lat 90. XX w. Dodatkowym niekorzystnym czynnikiem było wprowadzenie do sprzedaży modeli samolotów, których cena i koszty eksploatacji ograniczyły ich konkurencyjność na rynkach światowych i utrudniały sprzedaż.

Trzecia faza rozwoju, trwająca od połowy lat 90 . XX w. do chwili obecnej, charakteryzuje się prywatyzacją i restrukturyzacją przedsiębiorstwa Embraer, przy zachowaniu kontroli państwa oraz dominującego udziału w prywatyzacji kapitałów brazylijskich. Państwo wspomogło też proces restrukturyzacji i oddłużania przedsiębiorstwa. Sukces procesu restrukturyzacji związany był z wkroczeniem na nowy rynek odrzutowców pasażerskich średniego zasięgu i pojemności, który pozostawał poza zainteresowaniem głównych światowych firm Boeinga i Airbusa. Bardzo ważne okazały się też zmiany w organizacji produkcji, finansowaniu i marketingu, a szczególnie ograniczenie czasu potrzebnego na wprowadzenie projektu do sprzedaży oraz włączenie do projektu podwykonawców i kooperantów ponoszących odpowiedzialność za przygotowanie określonych części i podzespołów. Umożliwiło to firmie ograniczenie kosztów i czasu związanego z opracowaniem produkcji tych elementów we własnym zakresie lub koniecznością zakupu licencji. Dzięki włączeniu kooperantów do projektu i zlecając im opracowania i produkcji określonych podzespołów Embraer zyskiwał dostęp do nowych technologii i doświadczenia firm długo działających na rynku i pochodzących z państw wysokorozwiniętych oraz znacząco skrócił czas powstania prototypów i wdrożenia ich do produkcji.

Historia Embraera jest przykładem udanego przejścia od przedsiębiorstwa państwowego założonego i rozwijanego w myśl polityki industrializacji poprzez substytucję importu do prywatnego koncernu działającego $\mathrm{w}$ warunkach postępującej liberalizacji handlu zagranicznego i rosnącej konkurencji międzynarodowej. Prowadzona w czasie prywatyzacji i restrukturyzacji polityka rządowa i związane z nią wsparcie proeksportowe, a także kapitałowe, oferowane głównie przez Narodowy Bank Rozwoju (BNDES), pozwoliły firmie uniknąć bankructwa i umożliwiły rozwój, który doprowadził do tego, że stała się ona czwartym co do wielkości koncernem lotniczym na świecie. Embraer jest głównym światowym producentem 
W segmencie odrzutowców pasażerskich średniego zasięgu i dzieli ten segment rynku z kanadyjskim Bombardierem. W ostatnich latach poza tym segmentem koncern zwiększa swój udział w produkcji samolotów biznesowych oraz wojskowych, co wpisuje się w ogólną strategię firmy, zmierzającą do większej dywersyfikacji produkcji zabezpieczającej przed wahaniami popytu w poszczególnych segmentach rynku. Embraer jest również bardzo ważną firmą w kreowaniu nowego wizerunku dynamicznie rozwijającej się gospodarki brazylijskiej i zarazem symbolem jej sukcesu w ostatnich latach. Jest on jednym z największych eksporterów w kraju, będącym kilka lat na pierwszym miejscu z blisko 5\% udziałem w ogólnej wartości eksportu. Jest także jedynym brazylijskim przedsiębiorstwem w sektorze high-tech, któremu udało się odnieść sukces na skalę światową, jak również jedynym brazylijskim eksporterem wyrobów tego sektora.

\section{Literatura}

Cassiolato J.E., Bernardes R., Lastres H., 2003, Transfer of Technology for Successful Integration into the Global Economy, A case study of Embraer in Brazil, United Nations, UNCTAD, New York-Geneva.

Embraer Annual Report 1999, 2000, Embraer, São Jose dos Campos, http://www.embraer.com.br/relatorios_anuais/relatorio_1999/ing/index.htm.

Embraer Annual Report 2001, 2002, Embraer, São Jose dos Campos, http://www.embraer.com.br/relatorios_anuais/relatorio_2001/eng/index.htm.

Embraer Annual Report 2007, 2008, Embraer, São Jose dos Campos, http://www.embraer.com.br/relatorios_anuais/relatorio_2007/english/.

Embraer Annual Report 2008, 2009, Embraer, São Jose dos Campos, http://www.embraer.com.br/relatorios_anuais/relatorio_2008/english/flash.asp.

Embraer in Numbers, 2009, Embraer, São Jose dos Campos, http://www.embraer.com.br/english/content/imprensa/embraer_numeros.asp.

Embraer timeline, 2009, Embraer, São Jose dos Campos, http://www.embraer.com.br/timeline/english/.

Frischtak C.R., 1992, Learning, Technical Progress and Competitiveness in the Commuter Aircraft Industry: An Analysis of Embraer, Industry Series Paper, no. 58, Industry Development Division, World Bank, New York.

Goldstein A., 2002, EMBRAER: From national champion to global player, CEPAL Review, no. 77, s. $97-115$.

Goldstein A., McGuire M.S., 2004, The Political Economy of Strategic Trade Policy and the BrazilCanada Export Subsidies Saga, World Economy, vol. 27/4, s. 541-566.

Goldstein A., 2006, The Political Economy of Industrial Policy in China: The Case of Aircraft Manufacturing, Journal of Chinese Economic and Business Studies, vol. 4, no 3, s. 259-273.

Kanatsu T., 2006, Choice of national strategy and industrial organization comparing airframe production between Brazil and Japan, International Journal of Asia Pacific Studies, vol. 2, s. 1-27.

Mitchell R., 2005, The little aircraft company that could, Fortune, 11 July, s. 64-69.

Ramamurti R., 1985, High technology exports by state enterprises in LCCs: The Brazilian aircraft industry, Developing Economies, vol. 23/3, s. 254-280.

Mattos B.S., 2006, A Brief History of Brazilian Aeronautics, Proceedings of the 11-th Brazilian Congress of Thermal Sciences and Engineering - ENCIT, Curitiba. 


\section{Transformation and global expansion of the Brazilian aviation industry at the turn of the 21st century on the example of Embraer}

The aim of the study is to analyse the process of historical growth, transformation and global expansion of the largest Brazilian aircraft industry enterprise - Embraer (Empresa Brasileira de Aeronautica). The company history can be divided into three main stages. The first one lasted from 1969 until the second half of the 1980s. In that stage, the company developed production supported mainly by the government or on license technology. The second stage lasted from the end of the 1980s to the mid-1990s. This was the stage of the crisis and transformation of the company, which ended up with its privatization and recovery. The last stage, lasting from 1996 to 2009, was characterized by dynamic growth of production and sales. The new family of regional jets (ERJ-145 and Embraer 170/190) turned out to be a great selling success which has enabled the company to maintain its position as a global leader in regional jets, which vies with the Canadian Bombardier for the third place in the world ranking of aircraft manufacturers.

dr Mirosław Wójtowicz

Uniwersytet Pedagogiczny im. Komisji Edukacji Narodowej w Krakowie

Instytut Geografii

Zakład Geografii Społeczno-Ekonomicznej

e-mail: mwojt@up.krakow.pl 